\title{
Discordant umbilical arteries in the umbilical cord entanglement: a light microscope study
}

\author{
İrem Şenyuva1 (iD), Şirin Küçük ${ }^{2}$ \\ ${ }^{1}$ Department of Obstetrics and Gynecology, Uşak Training and Research Hospital, Faculty of Medicine, Uşak University, Uşak, Turkey \\ ${ }^{2}$ Department of Medical Pathology, Faculty of Medicine, $U_{s ̧}$ ak University, $U_{\S ̧}$ ak, Turkey
}

\begin{abstract}
Objective: The present study aimed to examine the histopathological diagnosis of the umbilical artery discordance in cases with single or multiple umbilical cord entanglement and pregnancy outcomes.

Methods: The vascular structure of the umbilical cord, histopathological findings of the placenta and obstetric outcomes were retrospectively examined in 50 cases. The cases were divided into two groups by the number of cord entanglement (single-multiple) and their histopathological findings and neonatal Apgar scores were assessed.

Results: Out of 50 cases, 38 (76\%) had single and 12 (24\%) had multiple cord entanglement. In 50 cases, the mean gestational age was $39.16 \pm 1.06$ weeks, neonatal Apgar scores were $8.7 \pm 0.58$ at 1 minute and $9.64 \pm 0.56$ at 5 minute. No statistically significant difference was detected between single and multiple groups in terms of gestational age $(\mathrm{p}=0.79), 1$-minute Apgar score $(\mathrm{p}=0.832)$ and 5-minute Apgar score $(\mathrm{p}=0.656)$. In histopathological examination, the diameters of umbilical arteries 1 and 2 were found to be $0.11 \pm 0.12,0.09 \pm 0.05 \mu \mathrm{m}$, respectively in the single group $(\mathrm{p}=0.756)$ and $0.13 \pm 0.14,0.06 \pm 0.02$ $\mu \mathrm{m}$, respectively in the multiple group $(\mathrm{p}=0.131)$. When the umbilical arterial diameters were compared by group, the diameter of the umbilical artery 2 was detected $0.09 \pm 0.05 \mu \mathrm{m}$ in the single and $0.06 \pm 0.02 \mu \mathrm{m}$ in the multiple group and statistically significant difference was detected ( $\mathrm{p}=0.037)$. Out of 50 cases, placental hypoxia finding was detected as chorangiosis only in 10 cases ( 2 multiple, 8 single). Conclusion: Umbilical artery discordance was detected in cases with multiple umbilical cord entanglement. However, poor pregnancy outcome was not observed in any of the cases. When multiple cord entanglement is seen during obstetric examination, umbilical artery discordance must be remembered and investigated, and also maternal-fetal condition should be considered.
\end{abstract}

Keywords: Umbilical cord, umbilical arteries, nuchal cord, discordance.

\section{Introduction}

Umbilical cord consists of two arteries, one vein and the surrounding Wharton's jelly. ${ }^{[1]}$ Two arteries and the vein form a helical structure to provide the feto-maternal

\section{Özet: Umbilikal kord dolanmasında uyumsuz umbilikal arterler: Işık mikroskobu çalışması}

Amaç: Calışmamızda tek veya çoklu umbilikal kord dolanması olan olgularda umbilikal arter uyumsuzluğuna yönelik histopatolojik tanıyı ve gebelik sonuçlarını incelemeyi amaçladık.

Yöntem: Umbilikal kordun vasküler yapısı, plasentanın histopatolojik bulguları ve obstetrik sonuçlar 50 olguda retrospektif olarak incelendi. Olgular kordon dolanması sayısına (tek-çoklu) göre iki gruba ayrıldı ve olguların histopatolojik bulguları ve neonatal Apgar skorları değerlendirildi.

Bulgular: Elli olgunun 38'inde (\%76) tek ve 12'sinde (\%24) çoklu kordon dolanması mevcuttu. 50 olgunun ortalama gestasyonel yaşı $39.16 \pm 1.06$ ve neonatal Apgar skorları 1. dakika için $8.7 \pm 0.58,5$. dakika için $9.64 \pm 0.56$ idi. Gestasyonel yaş $(\mathrm{p}=0.79)$, 1. dakika Apgar skoru $(\mathrm{p}=0.832)$ ve 5 . dakika Apgar skoru $(\mathrm{p}=0.656)$ bakımından tekli ve çoklu kordon dolanması gruplarında istatistiksel olarak anlamlı fark yoktu. Histopatolojik muayenede 1. ve 2. umbilikal arterlerin çap1 tek kordon dolanmasi grubunda sirasiyla $0.11 \pm 0.12,0.09 \pm 0.05 \mu \mathrm{m}$ $(\mathrm{p}=0.756)$ ve çoklu kordon dolanması grubunda ise sırasıyla $0.13 \pm 0.14,0.06 \pm 0.02 \mu \mathrm{m}(\mathrm{p}=0.131)$ olarak bulundu. Umbilikal arteryal çaplar gruba göre karşılaştırıldığında, umbilikal arter 2'nin çapı tek kordon dolanması grubunda $0.09 \pm 0.05 \mu \mathrm{m}$ ve çoklu kordon dolanmasi grubunda $0.06 \pm 0.02 \mu \mathrm{m}$ olarak bulundu ve istatistiksel olarak anlamlı fark vardı ( $\mathrm{p}=0.037$ ). Elli olgunun 10 'unda ( 2 çoklu, 8 tek) plasental hipoksi bulgusu sadece koranjiozis olarak tespit edildi.

Sonuç: Çoklu umbilikal kord dolanması olan olgularda umbilikal arter uyumsuzluğu tespit ettik, fakat olguların herhangi birinde kötü gebelik sonucu gözlemlemedik. Obstetrik muayenede çoklu kordon dolanması görülmesi halinde, umbilikal arter uyumsuzluğu hatırlanarak araştırılmalı ve ayrıca maternal-fetal durum dikkate alınmalıdır.

Anahtar sözcükler: Umbilikal kord, umbilikal arterler, nukal kord, uyumsuzluk.

blood supply. ${ }^{[1]}$ Umbilical cord is formed on the postconception 13-38 days and some anomalies such as cyst, supernumerary vessels and single umbilical artery may occur during its development..$^{[2-4]}$ Moreover, as a charac-

Correspondence: İrem Şenyuva, MD. Department of Obstetrics and Gynecology, Uşak Training and Research Hospital, Faculty of Medicine, Uşak University, Uşak, Turkey. e-mail: iremsenyuva@yahoo.com / Received: November 2, 2021; Accepted: December 2, 2021

How to cite this article: Şenyuva İ, Küçük Ş. Discordant umbilical arteries in the umbilical cord entanglement: a light microscope study. Perinatal Journal 2021;29(3):231-237. doi:10.2399/prn.21.0293009 
teristic of the early fetal development, umbilical cord entanglement may occur between 13 and 16 weeks of gestation and possible resolution may be seen in $63 \%$ of fetuses in the following weeks. ${ }^{[5]}$ Its incidence in term pregnancies is 5.5 to $22.8 \% .{ }^{[6]}$

The exact etiopathogenesis of the umbilical cord entanglement remains unknown. ${ }^{[7]}$ While it is usually seen as one or two loose loops around the fetal neck, it has also been reported to be seen as tight in $2-6 \%$, as multiple nuchal cords in $0.3-3.8 \%$, around the body in $4.7 \%$, around the lower extremities in $4.2 \%$ and around the several other parts of the fetus in $6.4 \% .{ }^{[5,8,9]}$ While the clinical importance of the cord entanglement is still controversial in the obstetric field, there is no consensus on whether it leads to poor pregnancy outcomes. ${ }^{[7,9]}$

While the lumina of the umbilical arteries are usually equal, a discordance of 1 to $3 \mathrm{~mm}$ was detected in various studies. ${ }^{[10]}$ The reasons for the discordance were thought to be factors including anomalies during the embryonic development and secondary atrophy. ${ }^{[2]}$ It has been reported that this might be associated with the placental and fetal anomalies, or it would not lead to any poor pregnancy outcome..$^{[10-12]}$

There are studies in the literature which detected the umbilical artery discordance by ultrasonography and/or histopathology, associated it with placental and umbilical cord pathologies, and compared the perinatal outcomes; however, no study was found to examine the discordance in cases with umbilical cord entanglement. ${ }^{[10,12-14]}$

The present study aimed to examine the histopathological diagnosis of the umbilical artery discordance in cases with single or multiple umbilical cord entanglement and its effects on pregnancy outcomes.

\section{Methods}

In our study, the files of the patients who delivered infants between January and December 2019 in Uşak Training and Research Hospital, Gynecology and Obstetrics Clinic were retrospectively screened. The cases with single or multiple cord entanglement and cord localization notes were detected on these files and their umbilical cord and placenta histopathology reports were reviewed from the computer records. Obstetric, neonatal and maternal demographic data of the cases were reviewed. Ethics committee approval for the was taken from the Ethics Committee of Uşak University's Faculty of Medicine on 23/12/2020 with the approval no. of 2214-14.

Umbilical vascular diameters measured by Olympus CX 41 light microscope (Olympus, Tokyo, Japan) on 4-6 $\mu$ sections of umbilical cord were reviewed from the histopathological examination reports on the specimens fixed in $10 \%$ formalin and the diameter and length of the umbilical cord and coiling under macroscopic examination were assessed. The total vascular diameters were calculated by measuring the transverse and vertical lengths of the umbilical vessels under light microscope in micrometer. ${ }^{[15]}$ Microscopic placenta findings related to hypoxia were investigated.

The method of delivery, maternal age, pregnancyparity, week of gestation were obtained from the obstetric data of the cases; and neonatal weight, 1-minute and 5-minute Apgar scores, sex, the number and the localization of cord entanglement were obtained from the neonatal data.

The cases were divided into two groups by the presence of single or multiple cord entanglement and the umbilical cord and placental histopathological findings and obstetric outcomes were compared.

Statistical analyses were performed using NCSS (Number Cruncher Statistical System) 2007 (Kaysville, Utah, USA) software. For the assessment of the study data, descriptive statistical methods (mean, standard deviation, median, frequency, ratio, minimum-maximum) were used with Shapiro-Wilk test for the assessment of the distribution of data. Student's t-test was used for the comparison of two groups with normally distributed quantitative data and Mann-Whitney $\mathrm{U}$ test for the comparison of two groups with non-normally distributed quantitative data. Chi-square test was used for the assessment of the qualitative data. Significance was evaluated at the $\mathrm{p}$-values of $<0.01$ and $<0.05$.

\section{Results}

Out of 50 cases in this study, 38 (76\%) had single cord entanglement and 12 (24\%) had multiple cord entanglement. The localization of the entanglement was neck in 45 cases, body and legs in 3 cases. True knot was detected in 2 cases. Table 1 shows the number and localization of the umbilical cord entanglements of the cases.

In 50 cases, it was found that the mean maternal age was $25.8 \pm 5.2$ years, week of gestation was $39.16 \pm 1.06$, 
number of pregnancies was $2.32 \pm 1.42$, parity was $1.06 \pm 1.25$, neonatal weight was $3306.3 \pm 458.99 \mathrm{~g}, 1$ minute Apgar score was 8.7 \pm 0.58 and 5-minute Apgar score was $9.64 \pm 0.56$. No statistically significant difference was detected in terms of the maternal and neonatal findings between the groups $(\mathrm{p}>0.05)$ (Table 2). There was not any abnormal finding during obstetric follow-ups.

Among 50 cases, the sex of the neonates was detected to be female in 28 cases (56\%) and male in 22 (44\%). The method of delivery was vaginal in 37 cases (74\%) and cesarean section in 13 (26\%). No vacuum delivery was observed. There was no statistically significant difference between groups in terms of the method of delivery $(\mathrm{p}=0.852)$ and the sex of the infant $(\mathrm{p}=0.331)$.

At the macroscopic evaluation of the umbilical cord; in 49 cases $(98 \%)$ umbilical cord was normocoil and 1 case $(2 \%)$ was hypercoil.

In the histopathological examination of the umbilical cord; umbilical artery 1 and 2 diameters were found $0.11 \pm 0.12$ and $0.09 \pm 0.05 \mu \mathrm{m}$, respectively $(\mathrm{p}=0.756)$ in the single entanglement group and $0.13 \pm 0.14$ and $0.06 \pm 0.02 \mu \mathrm{m}$, respectively $(\mathrm{p}=0.131)$ in the multiple entanglement group with no statistically significant difference was detected. When the diameters of umbilical artery 1 and 2, and the vein were compared by group, the diameter of the umbilical artery 2 was detected to be $0.09 \pm 0.05 \mu \mathrm{m}$ in the single and $0.06 \pm 0.02 \mu \mathrm{m}$ in the multiple entanglement group with statistically significant difference was obtained for discordance $(\mathrm{p}=0.037)$. No allantoic remnant was detected in the histopathological examination. Fig. 1 shows the umbilical vessel measurements, and Table 3 shows the histopathological findings of the umbilical cord.
Table 1. Number and localization of the umbilical cord entanglement.

\begin{tabular}{llcc} 
Umbilical cord entanglement & $\mathbf{n}$ & $\%$ \\
\hline \multirow{2}{*}{ Number } & Single & 38 & 76 \\
\cline { 2 - 4 } & Multiple $(>2)$ & 12 & 24 \\
\hline \multirow{3}{*}{ Localization } & Neck & 45 & 90 \\
\cline { 2 - 4 } & Trunk and limb & 3 & 6 \\
\cline { 2 - 4 } & True knot & 2 & 4 \\
\hline
\end{tabular}

In the microscopic evaluation of the placenta; hypoxia-related change was detected as chorangiosis only in 10 cases. Among them, 2 cases were in the multiple and 8 cases were in the single entanglement groups (Fig. 2).

No abnormal finding was found regarding Hyrtl's anastomosis, and volume and vascularity of the placenta in the pathology reports of the cases.

\section{Discussion}

In our study, umbilical arteries discordance was detected in the multiple entanglement group compared to single entanglement group.

During the embryonic development of the umbilical artery; primary agenesis, secondary atrophy and allantoic artery persistence, thereby, hypoplasia or single umbilical artery development may occur. ${ }^{[2]}$ Single umbilical artery is usually characterized with increased perinatal mortality and morbidity. ${ }^{[16]}$ Secondary atrophy may be seen as a result of the mechanical compression of the allantoic remnants or luminal bridging of the arteries. ${ }^{[2,16]}$ Due to lack of fetal anomalies in our cases and lack of allantoic remnants in the histopathological examination, discordance could be explained by the secondary atrophy induced by the compression effect of the multitude of cord entanglements.

Table 2. Maternal and neonatal findings of umbilical cord entanglement.

\begin{tabular}{|c|c|c|c|c|c|}
\hline & \multicolumn{2}{|c|}{ Single $(n=38)$} & \multicolumn{2}{|c|}{ Multiple $(n=12)$} & \multirow[b]{2}{*}{ p-value } \\
\hline & Mean \pm sd & Min-max & Mean \pm sd & Min-max & \\
\hline Maternal age & $25.61 \pm 5.36$ & $18-39$ & $26.42 \pm 4.83$ & $19-34$ & 0.642 \\
\hline Pregnancy & $2.18 \pm 1.37$ & $1-7$ & $2.75 \pm 1.54$ & $1-6$ & 0.06 \\
\hline Parity & $0.89 \pm 1.15$ & $0-6$ & $1.58 \pm 1.44$ & $0-5$ & 0.075 \\
\hline Week of gestation & $39.18 \pm 1.06$ & $37-42$ & $39.08 \pm 1.08$ & $38-41$ & 0.749 \\
\hline Baby weight (gram) & $3320.39 \pm 457.61$ & $2260-4350$ & $3261.67 \pm 480.8$ & 2350-4295 & 0.703 \\
\hline 1-minute Apgar score & $8.68 \pm 0.62$ & $7-10$ & $8.75 \pm 0.45$ & $8-9$ & 0.832 \\
\hline 5-minute Apgar score & $9.63 \pm 0.54$ & $8-10$ & $9.67 \pm 0.65$ & $8-10$ & 0.656 \\
\hline
\end{tabular}



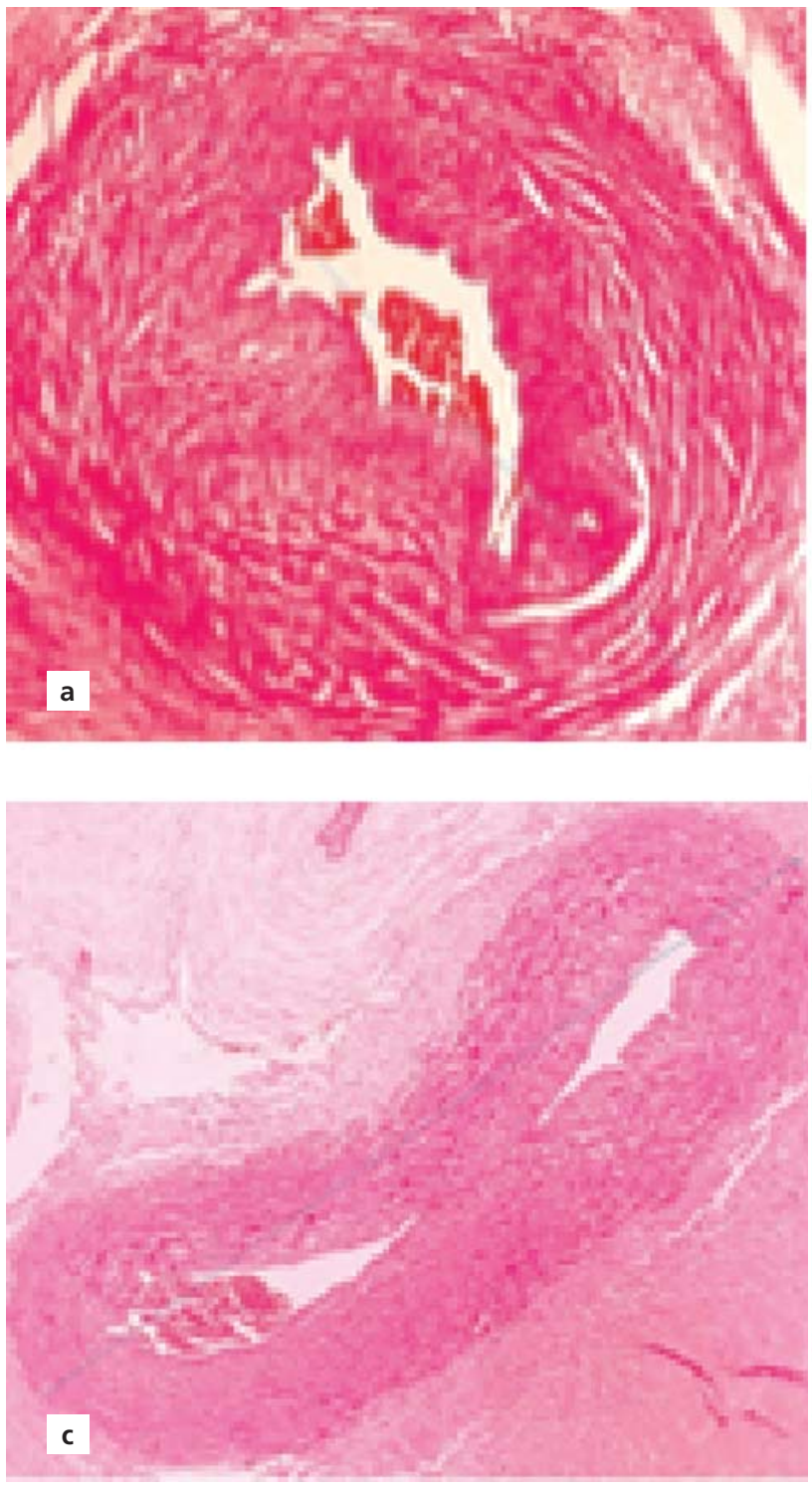

Fig.1. Light microscope view of umbilical vessels. (a) Umbilical artery 1 ; (b) umbilical artery 2 ; (c) Umbilical vein (H\&E $\times 40)$.

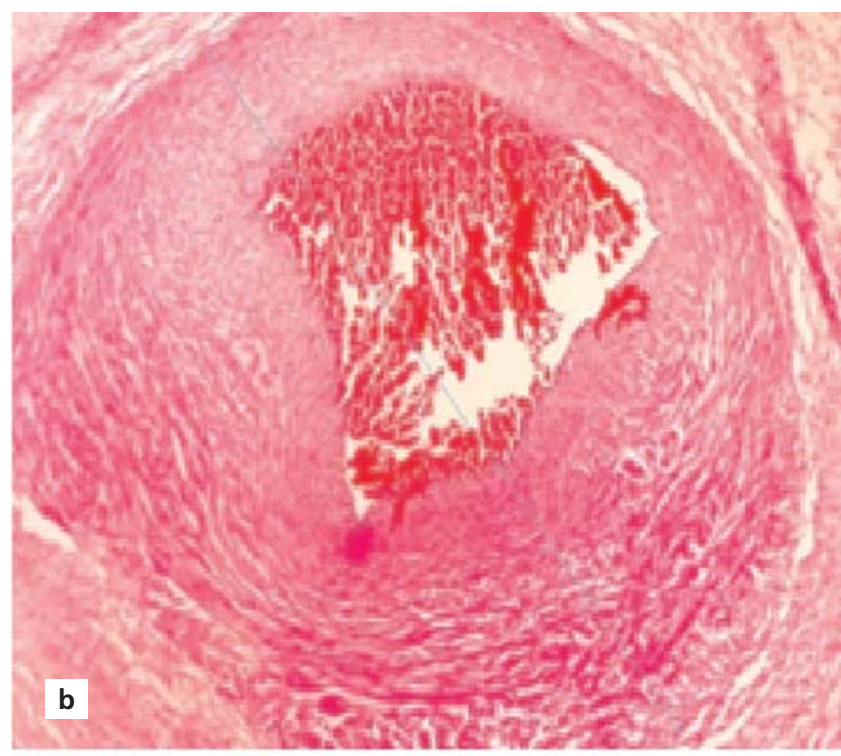

Umbilical artery discordance $(1-3 \mathrm{~mm})$ was first detected by Dolkart et al. in 6 of 721 cases at 20 weeks of gestation and among them, only 2 cases had poor obstetric outcomes. ${ }^{[3]}$ Some factors such as Hyrtl's anastomosis and compensation mechanism between arteries may protect against poor obstetrics outcomes; but on the other hand, discordance may accompany fetal abnormalities. ${ }^{[10,12-14]}$ In 14 cases, $>1 \mathrm{~mm}$ umbilical arteries discordance were detected between 24 and 42 weeks of gestation, but no negative effects on 5 -minute Apgar scores of the neonates was observed and explained as discordance being less and was compensated by the functional artery. ${ }^{[13]}$ Similarly, discordance was detected between umbilical arteries (large $1.8 \pm 0.3$ and small $1.1 \pm 0.3$ ) by ultrasonography at the second trimester in 12 of 154 term pregnancies, there was no poor obstetrics outcome in terms of the method of delivery, neonatal Apgar findings and placental pathol-

Table 3. Histopathologic findings of umbilical cord.

\begin{tabular}{|c|c|c|c|c|c|}
\hline & \multicolumn{2}{|c|}{ Single $(n=38)$} & \multicolumn{2}{|c|}{ Multiple $(n=12)$} & \multirow[b]{2}{*}{ p-value } \\
\hline & Mean \pm sd & Min-max & Mean \pm sd & Min-max & \\
\hline Umbilical cord length (cm) & $35.96 \pm 10.24$ & $18-65$ & $40.29 \pm 12.99$ & $28-69$ & 0.400 \\
\hline Umbilical cord diameter $(\mathrm{cm})$ & $16.97 \pm 1.57$ & $12-20$ & $16.83 \pm 1.52$ & 13-19 & 0.954 \\
\hline Umbilical artery $1(\mu \mathrm{m})$ & $0.11 \pm 0.12$ & $0.05-0.70$ & $0.13 \pm 0.14$ & $0.05-0.50$ & 0.795 \\
\hline Umbilical artery $2(\mu \mathrm{m})$ & $0.09 \pm 0.05$ & $0.05-0.3$ & $0.06 \pm 0.02$ & $0.05-0.1$ & 0.037 \\
\hline Umbilical vein $(\mu \mathrm{m})$ & $0.22 \pm 0.16$ & $0.05-0.70$ & $0.22 \pm 0.16$ & $0.05-0.60$ & 0.906 \\
\hline
\end{tabular}


ogy and explained as presence of Hyrtl's anastomosis. ${ }^{[10]}$ On the other hand, in 12 cases with trisomy 18 , intrauterine growth retardation, pulmonary stenosis, maternal diabetes and hypoplastic umbilical artery were detected by ultrasonography. ${ }^{[12]}$ Likewise in the literature, umbilical artery discordance was seen with fetal renal cyst, hydronephrosis and corpus callosum agenesis. ${ }^{[14]}$ The umbilical artery discordance did not result in poor pregnancy outcomes in our study and it can be explained by the usual maternal-fetal follow-up during antenatal period, and the discordance difference being less and compensated by the umbilical vessels.

The association between the umbilical cord entanglement and pregnancy outcomes is a controversial topic in the literature. In a meta-analysis of 267,233 pregnant women, an association has been reported between umbilical cord entanglement and 1-minute Apgar score being low and fetal acidosis. ${ }^{[9]}$ Similarly, in umbilical cord entanglement found in 698 of 2156 term pregnancies, neonatal oxygen requirement was significantly higher in multiple entanglement compared to single entanglement, and intensive care requirement in the multiple, single and no-entanglement groups were $14.4 \%, 7.2 \%$ and $8.3 \%$, respectively. ${ }^{[17]}$ In another study, the rate of intensive care requirement was $14 \%$ in the cord entanglement and $10 \%$ in the no-entanglement group. ${ }^{[18]}$ Stillbirth and growth retardation were reported related to umbilical cord entanglement. ${ }^{[5,19]} \mathrm{On}$ the other hand, cord entanglements in the neck and other parts of the body in 82 of 486 term pregnancies were detected as a significant correlation between cord entanglement and 1-minute Apgar score being low [r=0.1735 (CI 95\% 0.08322 to 0.2609)] but low correlation between cord entanglement and acidosis [r=0.09517 (CI 95\% 0.003616 to 0.1851)], and it was stated that cord entanglement did not result in poor pregnancy outcomes. ${ }^{[20]}$ Similarly, in a study that observed umbilical cord entanglement in 218 of 408 term pregnancies, poor pregnancy outcomes were not seen in any of the cases according to the American College of Obstetrics and Gynecology (ACOG) hypoxic ischemic encephalopathy criteria. ${ }^{[7]}$ There are some studies in the literature about no adverse perinatal outcomes of cord entanglement including neonatal intensive care requirement and Apgar score being low. ${ }^{[7,17]}$ Findings including diffuse villous hypervascularity, chorangiosis, laminar necrosis, chorionic microcyst,

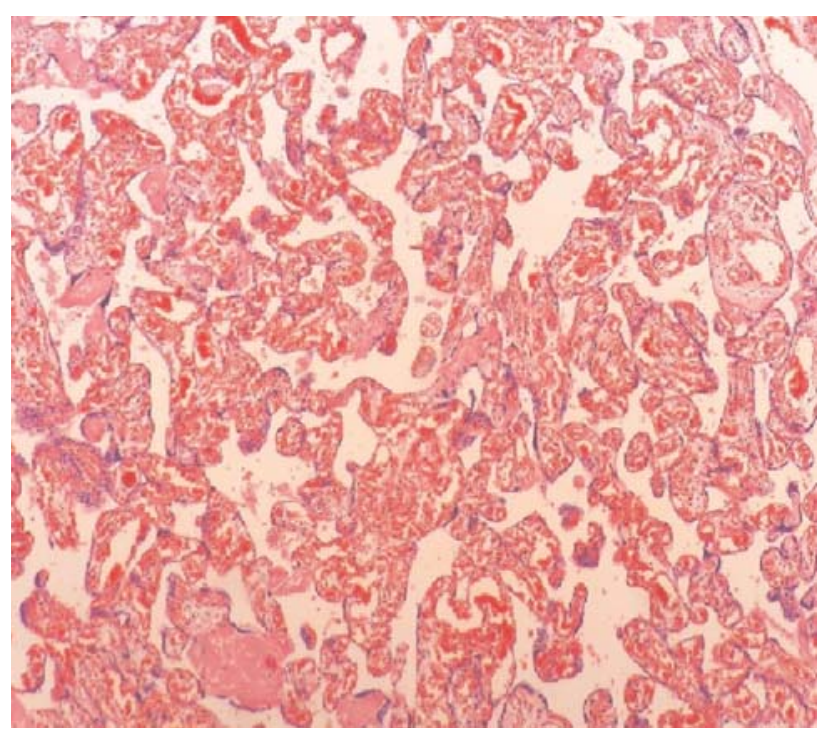

Fig. 2. Microscopic view of chorangiosis. The chorangiosis area representing the vascular hyperplasia seen in terminal chorionic villus structures (H\&E $\times 40)$.

thrombosis and $>5-10 \%$ infarction are hypoxia-related pathologies seen in histopathological examination of placenta. ${ }^{[21]}$ Chorangiosis is a terminal villi lesion which may occur due to hypo-oxygenation; its cause is not exactly known though genetic and environmental factors are also appear to be implicated. ${ }^{[2]}$ In our study, very few cases had chorangiosis and the other hypoxic lesions were not detected. The lack of poor obstetric outcomes despite umbilical artery discordance and cord entanglement may be explained by feto-maternal wellbeing and the lack of effect on blood transport due to the compensation mechanism of the umbilical cord.

Hyrtl's anastomosis, Wharton's jelly structure, coiling and localization of the cord may affect obstetric outcomes. The favorable obstetric outcomes observed in the presence of discordance in some studies were attributed to the protective role of the anastomosis. ${ }^{[23]}$ Wharton's jelly is a section adapting to vascular pulsation with its porous-fibrous structure and protecting them against conditions such as prolapse, knotting and entanglement. ${ }^{[1,24,25]}$ Furthermore, in case of hemodynamic changes, the mechanosensory properties of the cells in the umbilical cord tissue lead to changes in the structure of Wharton's jelly, thereby adapting it to the conditions. ${ }^{[1]}$ Hypocoil and hypercoil structures have been stated to be correlated with poor pregnancy out- 
comes such as Apgar score being low. ${ }^{[5,9,26,27]}$ The body localization is affected more by the uterine contractions compared to neck localization and is associated with higher rates of 5-minute Apgar score being low and acidosis. ${ }^{[28]}$ In our study, normocoil structure of the umbilical cord, neck localization, Hyrtl's anastomosis and possible adaptation mechanisms of Wharton's jelly can answer the question 'How were babies unaffected by tangles and discordance?', and to elucidate this, further immunohistochemical, morphometric and anatomic studies are needed.

\section{Study limitations}

There are several limitations to this study. The interval between the delivery and measurement is considered to result in a potential shrinkage in the umbilical cord due to formalin fixation. ${ }^{[27]}$ Since this is a retrospective study, the results involving measurements made on formalinfixed samples were used. Therefore, coiling status was indicated as hypo- or hypercoil, and was not indexed. Furthermore, patients' antenatal umbilical artery Doppler measurements could not be found in the medical records. Methods to measure Wharton's jelly area such as neural network and digital morphometry have been reported in the literature. ${ }^{[2,26]}$ Since light microscope was used in our study, only vascular diameters could be measured and area calculation could not be performed.

\section{Conclusion}

The present study has shown that multiple cord entanglement may cause umbilical artery discordance compared to the single entanglement, however, no poor pregnancy outcome was seen. When multiple cord entanglement is seen in obstetric follow-ups, umbilical artery discordance must be remembered and investigated, and also maternal- fetal condition should be considered.

Funding: This work did not receive any specific grant from funding agencies in the public, commercial, or not-for-profit sectors.

Compliance with Ethical Standards: The authors stated that the standards regarding research and publication ethics, the Personal Data Protection Law and the copyright regulations applicable to intellectual and artistic works are complied with and there is no conflict of interest.

\section{References}

1. Ferguson VL, Dodson RB. Bioengineering aspects of the umbilical cord. Eur J Obstet Gynecol Reprod Biol 2009; 144(Suppl 1):S108-13. [PubMed] [CrossRef]

2. Persutte WH, Hobbins J. Single umbilical artery: a clinical enigma in modern prenatal diagnosis. Ultrasound Obstet Gynecol 1995;6:216-29. [PubMed] [CrossRef]

3. Dolkart LA, Reimers FT, Kuonen CA. Discordant umbilical arteries: ultrasonographic and Doppler analysis. Obstet Gynecol 1992;79:59-63. [PubMed]

4. Şenyuva İ, Küçük Ş. A partial supernumerary umbilical vessels. J Clin Obstet Gynecol 2020;30:78-81. [CrossRef]

5. Dodds M, Windrim R, Kingdom J. Complex umbilical cord entanglement. J Matern Fetal Neonatal Med 2012;25:1827-9. [PubMed] [CrossRef]

6. Nkwabong E, Ndoumbe Mballo J, Dohbit JS. Risk factors for nuchal cord entanglement at delivery. Int J Gynaecol Obstet 2018;141:108-12. [PubMed] [CrossRef]

7. Akkaya H, Büke B, Pekcan MK, Şahin K, Uysal G, Yeğin GF, et al. Nuchal cord: is it really the silent risk of pregnancy? J Matern Fetal Neonatal Med 2017;30:1730-3. [PubMed] [CrossRef]

8. Redline RW. Clinical and pathological umbilical cord abnormalities in fetal thrombotic vasculopathy. Hum Pathol 2004;35:1494-8. [PubMed] [CrossRef]

9. Pergialiotis V, Fanaki M, Bellos I, Tzortzis A, Loutradis D, Daskalakis G. Evaluation of umbilical cord entanglement as a predictive factor of adverse pregnancy outcomes: a metaanalysis. Eur J Obstet Gynecol Reprod Biol 2019;243:150-7. [PubMed] [CrossRef]

10. Predanic M, Perni SC. Antenatal assessment of discordant umbilical arteries in singleton pregnancies. Croat Med J 2006; 47:701-8. [PubMed]

11. Raio L, Ghezzi F, Di Naro E, Gomez R, Saile G, Brühwiler H. The clinical significance of antenatal detection of discordant umbilical arteries. Obstet Gynecol 1998;91:86-91. [PubMed] [CrossRef]

12. Petrikovsky B, Schneider E. Prenatal diagnosis and clinical significance of hypoplastic umbilical artery. Prenat Diagn 1996; 16:938-40. [PubMed] [CrossRef]

13. Raio L, Ghezzi F, Di Naro E, Franchi M, Brühwiler H. Prenatal assessment of the Hyrtl anastomosis and evaluation of its function: case report. Hum Reprod 1999;14:1890-3. [PubMed] [CrossRef]

14. Sepulveda W, Flack NJ, Bower S, Fisk NM. The value of color Doppler ultrasound in the prenatal diagnosis of hypoplastic umbilical artery. Ultrasound Obstet Gynecol 1994;4:143-6. [PubMed] [CrossRef]

15. Malas MA, Sulak O, Gökçimen A, Sari A. Morphology of umbilical vessels in human fetuses: a quantitative light microscope study. Eur J Morphol 2003;41:167-74. [PubMed]

16. Persutte WH. Single fetal umbilical artery: a case report. J Diagn Med Sonogr 1994;10:161-3. [CrossRef]

17. Mariya T, Fujibe Y, Shinkai S, Sugita N, Suzuki M, Endo T, et al. Multiple part umbilical cord entanglement and neonatal 
outcomes. Taiwan J Obstet Gynecol 2018;57:672-6. [PubMed] [CrossRef]

18. Jauniaux E, Ramsay B, Peellaerts C, Scholler Y. Perinatal features of pregnancies complicated by nuchal cord. Am J Perinatol 1995;12:255-8. [PubMed] [CrossRef]

19. Bernad ES, Craina M, Tudor A, Bernad SI. Perinatal outcome associated with nuchal umbilical cord. Clin Exp Obstet Gynecol 2012;39:494-7. [PubMed]

20. Walla T, Rothschild MA, Schmolling JC, Banaschak S. Umbilical cord entanglement's frequency and its impact on the newborn. Int J Legal Med 2018;132:747-52. [PubMed] [CrossRef]

21. Stanek J. Placental hypoxic overlap lesions: a clinicoplacental correlation. J Obstet Gynaecol Res 2015;41:358-69. [PubMed] [CrossRef]

22. Küçük Ş, Şenyuva İ. Placenta and umbilical cord histopathologies in pathologic specimens and relationship between pregnancy outcomes. Selçuk Medical Journal 2019;35:1-8. [CrossRef]

23. Ullberg U, Sandstedt B, Lingman G. Hyrtl's anastomosis, the only connection between the two umbilical arteries. A study in full term placentas from AGA infants with normal umbilical artery blood flow. Acta Obstet Gynecol Scand 2001;80:1-6. [PubMed] [CrossRef]
24. Kurita M, Hasegawa J, Mikoshiba T, Purwosunu Y, Matsuoka $\mathrm{R}$, Ichizuka $\mathrm{K}$, et al. Ultrasound evaluation of the amount of Wharton's jelly and the umbilical coiling index. Fetal Diagn Ther 2009;26:85-9. [PubMed] [CrossRef]

25. Sobolewski K, Bafkowski E, Chyczewski L, Jaworski S. Collagen and glycosaminoglycans of Wharton's jelly. Biol Neonate 1997;71:11-21. [PubMed] [CrossRef]

26. Rogers MS, Ip YW, Qin Y, Rogers SM, Sahota D. Relationship between umbilical cord morphology and nuchal cord entanglement. Acta Obstet Gynecol Scand 2003;82:32-7. [PubMed] [CrossRef]

27. Khong TY. Evidence-based pathology: umbilical cord coiling. Pathology 2010;42:618-22. [PubMed] [CrossRef]

28. Kobayashi N, Aoki S, Oba MS, Takahashi T, Hirahara F. Effect of umbilical cord entanglement and position on pregnancy outcomes. Obstet Gynecol Int 2015;2015:342065. [PubMed] [CrossRef]

29. Thomas MR, Bhatia JK, Kumar S, i Boruah D. The histology and histomorphometry of umbilical cord cross section in preeclampsia and normal pregnancies: a comparative study. J Histotechnol 2020;43:109-17. [PubMed] [CrossRef]

This work is licensed under the Creative Commons Attribution-NonCommercial-NoDerivs 4.0 Unported (CC BY-NC-ND4.0) License. To view a copy of this license, visit http://creativecommons.org/licenses/by-nc-nd/4.0/ or send a letter to Creative Commons, PO Box 1866, Mountain View, CA 94042, USA.

Publisher's Note: The content of this publication does not necessarily reflect the views or policies of the publisher, nor does any mention of trade names, commercial products, or organizations imply endorsement by the publisher. Scientific and legal responsibilities of published manuscript belong to their author(s). The publisher remains neutral with regard to jurisdictional claims in published maps and institutional affiliations. 